\title{
Nigerian Pidgin: A Means of Human Development
}

\author{
Charles Chukwuma Motanya \\ http://dx.doi./org/10.4314/ujah.v18i2.10
}

\begin{abstract}
Growth and development are the target of every human being. There are several avenues for achieving this said development and one of such means is through the development of a viable language that will aid in people's effective communication for gains. This paper therefore explores the effective use of Nigerian Pidgin in the development of artistes in Nigeria's entertainment industry. Data were generated from a library research. The study is based on systemic-functional grammar. The findings indicate that Nigerian Pidgin has offered many artistes the opportunity to showcase to the wider public their works. This in turn, improves their financial and social status. The research recommends that Nigerian Pidgin should be adopted and included among one of Nigeria's official language.
\end{abstract}

\section{Introduction}

One of the most important differences between man and animal is man's ability to speak and make others understand him. Language is the only means through which this is achieved in man's life. Language is the medium or vehicle for conveying ideas, a system of arbitrary vocal symbol based on social cooperation; the totality of meaningful utterance in a given society (Yule 15). Language is a system of conventional or written symbols by means of which humans as members of a social group and participants in its culture communicates (Encyclopedia Britannica, 2002). Language determines and defines man's humanity. 
In Nigeria, we have three major indigenous languages that have national status. They include: Igbo, Hausa and Yoruba. Despite their national status, they are very limited in their coverage with regard to the entire country Nigeria and the outside world. This the researcher believes is the reason for making English language the official language of Nigeria. In a densely multilingual Nigeria, English has more government backing and a very high status as the official language (Adegbija 75, Obi 36). Consequently, it is the language in which the government carries out its official business and does other official transactions (section 55 of 1999 constitution of Federal Republic of Nigeria). The roles assigned to English include language of Education, language of international communication, language of the mass media and language of commerce, among others. With the status and functions conferred on the language by the government, many Nigerians tend to accord English with much prestige than they do any other language in the country, especially with reference to Nigeria Pidgin perceived as a deviant form of English by the educated ones (Elugbe and Omamer 148, Akande and Salani 74, Omoniyi 63, Obi 43).

On the other hand, Nigeria Pidgin, though viewed by some people as a 'nonstandard', is understood and spoken by a greater percentage of the linguistically heterogeneous Nigerian people (Balogun, 96). It has no explicit official patronage or serious recognition, yet it is used by both educated and uneducated Nigerians in inter-ethnic communication, when compared to the use of English (Esizimetor qtd. in Endong 1). It is no overstatement to say that pidgin functions as language of wider communication in Nigeria. According to Giwa, no language is widely and better used than Nigerian Pidgin yet, on official ground, it does not exist (17). 
Following the simplicity, wider coverage, and the neutral status of Nigerian Pidgin, many Nigerians have seized the opportunity to make a living through employing Nigerian Pidgin henceforth NP in their art. This paper therefore seeks to explore the reason and the use of NP as a means of human development.

\section{The Problem}

Nigeria is a country made up of over one hundred and sixty million people (National Population Commission 2015). The country is blessed with so many able men and women. These men and women are distributed into graduates from different fields, manual workers of different jobs etc. Majority among the above mentioned people are unemployed because they believed they will get a white collar job which most times is not forthcoming.

This paper therefore seeks to explore a growing but already flourishing entertainment industry which has gainfully employed a lot of Nigerians. The researcher believes that without the role of $\mathrm{NP}$ as the medium, for most music and jokes in Nigeria, most youth in the industry would not have been there. Also, the kind of acceptance and patronage that Nigerian music and jokes have over other music imported into the country, would not have been possible.

\section{Hypothesis}

The following hypotheses have been designed to guide this study:

i. NP popularized the Nigeria's entertainment industry.

ii. NP offered the opportunity for more people to participate in Nigeria's entertainment industry. 


\section{Scope}

This research will be limited to the origin of NP and its role in human development especially in music and jokes in Nigeria's entertainment industry.

\section{Theoretical Framework}

NP in a language which some people still regard as marginal of inferior language. This language is functionally very important and has served various communicative purposes in literature, business and the entertainment industry. The use of NP or a variety of language must take into consideration the 'context' of its use for it to yield maximum intended meaning. This kind of study finds its place in the systemic functional theory.

Systemic functional theory is an approach to language initiated by Firth and later developed by Halliday. One of its central concerns in the study of language is, context. Context is often more important than language structure. The term 'systemic' refers to the view of language as a network of systems, or interrelated sets of options for making meaning. The term 'functional' indicates that the approach is concerned with the contextualized, practical uses to which language is put as opposed to formal grammar. The model reviewed is context oriented and hinged on the functional use of language; correctness or well-formedness is not a matter here. This perspective is important in this research, as it expounds on the importance of language in social context. This will help understand that no language is inferior nor bad as some people have that notion about NP. 


\section{Pidgin and the Rise of Nigerian Pidgin}

According to Hudson, pidgins are varieties created for very practical and immediate purpose of communication between people who otherwise would have no common language whatsoever (61). This view is in consonance with Todd's definition of pidgin as a marginal language which arises to fulfill certain communication needs among people who have no common language (1).

Hudson and Todd believe that pidgin emerges as a result of the need for communication between people who have different languages. Holm defines pidgin as:

A reduced language that results from extended contact between groups of people with no language in common; it evolves when they need some means of verbal communication, perhaps for trade, but no group learns the native language of any other group for social reasons that may include lack of trust or of close contact (4).

Wardhaugh opines that:

a pidgin is a language with no native speakers: it is no one's first language but is a contact language. That is, it is the product of a multilingual situation in which those who wish to communicate must find or improvise a simple language system that will enable them to do so (15).

According to crystal, pidgin is viewed as a term used in sociolinguistics to refer to a language with a markedly reduced grammatical structure, lexicon stylistic range compared with other languages, and which is a native language of no one (369). The above definitions are all associated with the developmental stages 
of pidgin. Today, pidgin has developed into full languages in most nations where they are used as a medium of communication. It has been nativized to suit communication purposes in such nations. In some places, it has creolized and used as a mother tongue by some communities.

NP, like most pidgins spoken in different places all over the world, came about from the contact between Nigeria and their colonial masters, (Britain). Due to the initial trading contacts between Nigerians and the Portuguese in the Niger Delta region of Nigeria, NP has elements from the Portuguese language; such words includes, 'dash', 'palaver'. After the colonial era, NP continued to wax strong. This is because of the multilingual, multiethnic nature of Nigeria and the increasing urbanization and general migration all over Nigeria. A good number of rural dwellers moved to the cities in search of a better life. These immigrants from different ethnic groups in Nigeria had need to communicate with one another and the language they resorted to was NP because of its simplicity and neutrality. Mafeni has it that:

NP is essentially a product of the process of urbanization. While its origin lies historically ... on the coast, its development and spread is the result of contacts between Africans. The rapidly growing towns of Nigeria have increasingly become the melting pots of the many tribes and races which constitute Nigeria and pidgin seems to be today a very widely spoken lingua franca, many towns and city dwellers being at least bilingual in pidgin and an indigenous language (qtd. in Elugbe and Omamer 15). 
Akindele and Adegbite speaking on NP, said that the language is a blend of the indigenous language of the West African coast and those of foreign traders. They also believed that the language is a lingua franca used in Nigeria. Jowitt believes that NP originated and developed its standard forms during the period of 300 years that elapsed between the sixteenth and nineteenth centuries. Its vocabulary is drawn mostly from English, with Portuguese as the source of such common words as 'dash', 'palaver' and 'sabby'. He said that the syntax of pidgin has been heavily influenced by the languages of the southern Nigeria. With the amalgamation of north and south under one administration in 1914, traveling and residence outside the ethnic homelands and the mingling of ethnic groups in large towns and cities and in the army and the police became much more common than before, and these changes assisted the development of pidgin's new role. The situation today is that NP flourishes as a medium of inter-ethnic communication, especially in the south and in large cities with many nonindigenous residents or throughout states with many small ethnic groups (Jowitt 13).

NP is a language of wider communication which is used in crossethnic interaction. It is mass oriented as it is used by all the sectors of the linguistic community which it operates. In summary, NP shares with English the unique feature of being the only ethnically neutral language in Nigeria. It is spread all over Nigeria and spoken by Nigerians of different ethnic origins, it is indigenous to Nigeria because it originated, sustained and expanded in Nigeria.

\section{Nigerian Pidgin and Nigeria's Entertainment Industry}

Nigeria, Ghana, South Africa and some other African countries were colonized by the British. These countries all use the 
Whiteman's language (English) as the medium of communication among its different tribes. Unfortunately, the English language has limited number of speakers and so does not cover a wider range of the population especially in Nigeria. Music and jokes rendered in English alone always have limited listeners leading to limited patronage. This necessitated the use of NP a language of the masses, a language that cuts across ethnic and religious barriers in the entertainment industry. The musicians and comedians compete with millions of others on every level especially from their lyrics in terms of content. It is obvious that most popular music and jokes in the world are rendered in English language whether they are produced by English native speakers or not. This makes for lack of originality because when a Nigerian is singing or making a joke from his local environment in English, the content looses the local flavour which may have been captured by NP.

So, if the music or joke had been rendered in NP which captures Nigeria's local colour, it will be something new in the international domain as original art from Nigeria. This will mark it out from other kind world over. And here in Nigeria, the music or joke will also have wider listeners and patronage as Nigerians will appreciate it as their own. The highest gain in using NP is that many youth who would not ordinarily have gone into entertainment because of language barrier (English), have seized the opportunity offered by a simpler and neutral language 'NP' to flourish in the industry. NP has given Nigerian music and jokes a unique brand both in and outside Nigeria. Whenever people say, 'play us any naija track' it means that Nigerian music mostly rendered in NP is desired so are jokes. So, many men and women have been made popular in Nigeria and the wider world because of their style of using NP in their art. First among such people is the 
late Afrobeat king Fela Anikulapo Kuti who the researcher will say is the father of modern music rendered in NP in Nigeria.

Recently, with the growing and popularization of Nigeria's entertainment industry, many unemployed youths are smiling to the banks because of their music and jokes rendered in NP. These youths before joining the industry were jobless, some of them involved themselves in immoral acts and such ungainful acts set back their different communities. But with their new found job, they not only cater for themselves but train and employ other unemployed to their music or joke industry or other businesses they opened. This progress would not have been possible if not for the viability of NP as the medium of music and joke in Nigeria's entertainment industry. People like Tuface Idibia, P-Square Don Jazzy, D-Banj, Timaya, Flavour. Waje, Shey Shay, Tiwa Savage, Wizkid, Olamide, Harry's Song, Terry G, Dr Sid, Orezi, Femi Kuti, Phyno, Chidimma, Kcee, Korede Bello, Dija to mention a few are all celebrities courtesy their use of NP in their music.

Among the humourist we have people like Ali Baba, Klint de Drunk, Bovi, Basket Mouth, Julius Agwu, I go dye, AY and a host of others who are presently celebrities courtesy their use of NP in their jokes. Of the over four hundred indigenous languages spoken by Nigerians, only NP enjoys the privilege of being spoken by people from all walks of life and social strata. This offers it the wide coverage it has in essence leading to more patronage of music and jokes rendered in it.

\section{Human Development and Nigerian Pidgin}

Human development can be simply defined as a process of enlarging choices. Everyday human beings make a series of 
choices - some economic, some social, some political, some cultural. Human development is about freedoms, opportunities and improving the well-being of the populace. It is both a process and an outcome. It is concerned with the process through which choices are enlarged but it also focuses on the outcomes of enhanced choices.

Human development thus defined represents a simple notion, but with some implications. First, human choices are enlarged when people acquire more capabilities and enjoy more opportunities to use those capabilities. Human development seeks not only to increase both capabilities and opportunities but also to ensure an appropriate balance between them in order to avoid the frustration that a mismatch between the two can create.

Second, as already implied, economic growth needs to be seen as a means, albeit an important one, and not the ultimate goal of development. Income makes an important contribution to human well-being, broadly conceived, if its benefits are translated into more fulfilled human lives.

Third, the human development concept, by concentrating on choices, implies that people must influence the processes that shape their lives. They must participate in various decision-making processes, the implementation of those decisions, and their monitoring and adjustment to improve outcomes where necessary. Human development is development of the people, development by the people and development for the people. Development of the people involves building human capabilities through the development of human resources. Development by the people emphasizes that people must be able to participate actively in 
influencing the processes that shapes their lives and development for the people implies that the benefits of growth must be translated into the lives of people.

In the ultimate analysis, development means opportunities for the improvement of the well-being of man. NP has actually performed this function for the teeming unemployed Nigerians and those who wished to go into music and jokes as careers. The rise of NP and its increasing use in domains hitherto dominated by English is directly attributable to its increasing recognition as a medium of easy communication by the masses, as well as to the interest of some members of the Nigerian elite such as Wole Soyinka, Chinua Achebe, Ezenwa-Ohaeto, Amos Tutuola. These literary giants have successfully communicated effectively with NP in their various works.

Humourist in Nigeria's entertainment industry such as Mr-Ibu, Basket Mouth, Wint de Drunk, Teju Babyface, Julius Agwu, Ali Baba, Bovi etc. are all very successful millionaires today because the medium of their art is NP. Musicians are not left out. A keen observer of Nigeria's music industry, will agree that a lot of innovation has been introduced by artistes in the industry. These musicians demonstrate creative ingenuity in the way they blended Nigeria languages and NP. One can hardly listen or watch any music without noticing the creative use of NP and a Nigerian language. Musicians like Flavor, African China, Don Jazzy, Tiwa Savage, P-Square, Kcee, Dr. Sid, Tuface, Fela Anikulapo Kuti, Femi Kuti etc. are all outstanding because of what they did with NP. NP is not just an ordinary language but a tool for enlarging people's freedom, opportunities and improving their well-being. 


\section{Conclusion}

It is evident that NP which is spoken by many Nigerians, serves as a means of wider communication to the teeming population of Nigerians. And as a result, a better option for the entertainers for more participation and more patronage. NP shares with English the unique feature of being the only ethnically neutral language in Nigeria. It has really taken over as the all-purpose language which apart from hiding one's identity in a tribe-conscious society like Nigeria, makes one fit in the society of both the educated and the less educated. In summary, it detribalizes the user and serve as a bridge between social isolation of the elite and social inferiority of the less privileged. The above qualities of NP make it the best medium for any art that targets mass audience.

Charles Chukwuma Motanya College of Education, Azare charlliusaid@yahoo.com

\section{Works Cited}

Adegbija, E. "Language Attitude in Nigeria: a Panoramic View". Licca Research Reports on Language in Africa. Lagos: LICCA, 1993. Print.

Akande, A. The Verb in Standard Nigerian English and Nigerian Pidgin English: A Sociolinguistic, Approach. Unpublished Ph.D Dissertation, University of Leeds, 2008. Print.

Akindele, F. and Adegbite, W. The Sociology and Politics of English in Nigeria: An Introduction. Obafemi Awolowo University Press, 1999. Print. 
Balogun, T. In Defense of Nigerian Pidgin: Journal of Languages and Culture, Vol. 4(5), (2003): 90-98.

Crystal, D. A Dictionary of Linguistics and Phonetics $\left(5^{\text {th }}\right.$ ed.) Oxford: Blackwell. 2003. Print.

Elugbe, B and Omamor, A. Nigerian Pidgin: Background and Prospects. Ibadan: Heinemann Educational Books, 1991. Print.

Endong, F. "The use of Nigerian Pidgin English Print Advertising: Deviation from Standard Orthography and Effectiveness". International Journal of Art, Culture, Design and Language Works, vol. 1(1), (2005): 1-7. Print.

Halliday, $\mathrm{M}$ and Mathiessen. An Introduction to Functional Grammar. United Kingdom: Hodder Education, 2004. Print.

Holm, J. Pidgin and Creoles. Cambridge: Cambridge University Press, 1987. Print.

Hudson, R. Sociolinguistics. Cambridge: Cambridge University Press, 1982. Print.

Jowitt, D. Nigerian English Usage: An Introduction. Nigeria: Longman, 1991. Print.

Mafeni, B. 'Nigerian Pidgin' in Spenser, J. (ed.), The English Language in West Africa, Longman, London (1971): 95112. Print.

Obi, E. Language Attitude and Nigerian Pidgin: International Journal of Arts and Humanities. Vol. 3(4). (2014): 34-46.

Omoniyi, F. Pidgins as National Languages in Some African Countries: The Hurdles and the Way Forward. Ibadan, Musofo Publishers, 2016. Print.

Todd, L. Pidgin and Creoles. London: Routledge and Kegan Paul, 1994. Print.

Wardhaugh, R. An Introduction to Sociolinguistic ( $3^{\text {rd }}$ ed.) Oxford: Blackwell Publishers, 1998. Print. 